\title{
THE INFLUENCE OF THE GEOGRAPHICAL AREA ON WINE PRODUCTS. A CASE STUDY
}

\author{
Camelia Slave $^{1}$
}

DOI: https://doi.org/10.31410/ITEMA.2019.93

\begin{abstract}
Geographic Information Systems allows visualization of spatial data (data with an associated GPS location) in the form of a map and analyzes the relationships and patterns between data layers. Geographic Information Systems (GIS) create friendly maps that are visually understood by both growers and researchers.

By reporting different data collections in a geographic area, Geographic Information System, can help manufacturers better understand spatial models and relationships to make management decisions. Variability in a geographical area has economic consequences; Understanding this variability is the first step towards efficient vineyard management.
\end{abstract}

From a digital altitude model - DEM (a grid that covers the known territory) we can deduce:- hypsometric map, to define the area for producing certain varieties of wine vertically; soil map, to define areas with soil type; CLC map showing the coverage of the land; relief units map, types of geomorphological units in the study area.

The purpose of the article is to present the current situation of vineyards located in the Vrancea County.

Keywords: Geographical Information Systems (GIS), Production, Maps, Viticulture.

\section{INTRODUCTION}

$\mathrm{T}$ he origins of the vineyards are losing in time. The archaeological excavations discovered fossils and plants in warehouses dating from the Paleocene and Eocene period. Today there are rough 24.000 of vine varieties, of these only 150 are used in a generalized way and of these 9 varieties produced the classical wines. [8] The vine corresponds to the genus Vitis, it classified distinctly way in the family Vitaceae, Vitidaceae, Ampelidaceae, it is belonging botanical order of Rhamnales, but included the Rhamnaceae and Leeaceae family. The genus Vitis is subdivided into two subgenuses: Euvitis (authentic grapes) and Muscadinia (her fruit is called muscadin).

The first regions where the wine appeared, that think was certified by archaeological discoveries are in Armenia and Azerbaijan. From these areas it reaches in Greece (oinos) and Rome (vinum). From Rome it spreads to the Roman provinces. Once time the vine is introduced into the Roman Empire, the way of organizing the territory begins to improve, land improvement (irrigation, drainage), different planting distances (for common and tree-bearing crops), fertilization (organic, green, liquid).

The vineyard plantation is mentioned among the first agricultural crops on the territory of ancient Dacia. There are evidences that the first traces of viticulture activity in the present territo-

1 University of Agronomic Sciences and Veterinary Medicine of Bucharest, 59 Mărăști Blvd, Bucharest, Romania 
ry of Romania date back to the Neolithic period, when the gathering and hunting tribes became stable, they are practicing agriculture and animals' husbandry. [3] [5]

In Mesopotamia (today Iraq), the vineyards dates from the 4th millennium BC, more exactly, from the Sumerian period. The first consignment was doing by Strabo (63 BC-19 BC), he describes the fact that the vineyards horns were very large, so two people could reach them with their extended arms.

In ancient Hebrew is mentioned the existence of the famous „Chanaan grape” today being the variety of Raisin vine of Palestine. In the old Babylon the vineyard was used for food and landscape. [8]

The situation of vineyards plantations. Today, more than half of the total area planted, worldwide, with vineyards is in Europe. In Asia the largest plantations there are in Iran, Turkey and China. The highest density of plantations from Africa is founding in Egypt and South Africa. In South America, the largest plantations are founding in Argentina, Brazil and Chile.

Since 2010 in Europe, the area planted with vineyards has been reduced because to adapt the provisions of the Wine Market Common Organization, as follows:

- France reduced the area planted by $1 \%$ to 825,000 ha,

- Italy reduces the area cultivated by $2 \%$ and has 798,000 ha of vine,

- Of worldwide Argentina, Chile and the United States have maintained same area cultivated during Brazil, China and New Zealand increased by 1\%, Australia has reduced cultivated area by $3 \%$ and South Africa by $1 \%$.

The geographic information systems can be seen as a useful tool in agriculture because some goals can be reached more easily by monitoring input and output data. So, it can also reduce the negative effects on the environment. [11]

\section{VINEYARD OF ROMANIA}

Among the wine producing countries of the European Union, Romania occupies the 5th place on the vineyard surface, 6th place on the production of grapes and wine and owns one third of European Union vineyards. At national level, the area cultivated with vines occupies about $1.4 \%$ of the entire agricultural area of the country, and the South-East region owns $41.5 \%$ of this area.

The explication of this performance resides in the unique or difficult to imitate local resources: in the South-East region there is an extensive area cultivated with vineyards and a long wine-growing tradition, supported by the favorable climate and the sub-regions soils specific. The South-East region produces $43 \%$ of the Romanian wines, being the first place in the country in terms of the area of the vineyards, with $40.2 \%$ of the wine area of the country - mostly located in Vrancea County. In Vrancea county are cultivated about 25,000 ha with vineyard - of which "only about 3,000 hectares with harvest declaration. Vrancea is strongly divided, with about 10.000 owners in the area.

Table no 1. shows the production site per hectare for the period 2013 - 2017. It is noted that during this period there is an increase in production in the private sector and in individual agriculture holding. 2014 is an exception because we have a production decrease. 
Table 1. Average production of grapes per hectare, by ownership

\begin{tabular}{|c|c|c|c|c|c|c|c|}
\hline \multirow{4}{*}{$\begin{array}{l}\text { Vineyards } \\
\text { categories }\end{array}$} & \multirow{4}{*}{ Property forms } & \multirow{4}{*}{$\begin{array}{c}\text { Macroregions, } \\
\text { development regions } \\
\text { and counties }\end{array}$} & \multicolumn{5}{|c|}{ Years } \\
\hline & & & 2013 & 2014 & 2015 & 2016 & 2017 \\
\hline & & & \multicolumn{5}{|c|}{$\mathrm{Kg} / \mathrm{ha}$} \\
\hline & & & $\mathrm{Kg}$ & $\mathrm{Kg}$ & $\mathrm{Kg}$ & $\mathrm{Kg}$ & Kg \\
\hline \multirow{3}{*}{$\begin{array}{c}\text { Totally } \\
\text { - fruit } \\
\text { vineyards }\end{array}$} & Total & Vrancea & 6609 & 5615 & 5926 & 5809 & 7044 \\
\hline & Private sector & Vrancea & 6558 & 5621 & 5907 & 5794 & 7032 \\
\hline & $\begin{array}{l}\text { of which: Individual } \\
\text { agricultural holdings }\end{array}$ & Vrancea & 6420 & 5547 & 5692 & 5498 & 7001 \\
\hline \multirow{3}{*}{$\begin{array}{l}\text { Grafted } \\
\text { vineyard }\end{array}$} & Total & Vrancea & 6763 & 5894 & 6231 & 6134 & 7075 \\
\hline & Private sector & Vrancea & 6707 & 5904 & 6213 & 6120 & 7061 \\
\hline & $\begin{array}{l}\text { of which: Individual } \\
\text { agricultural holdings }\end{array}$ & Vrancea & 6573 & 5854 & 6004 & 5823 & 7028 \\
\hline
\end{tabular}

Source: Romania’s Statistical Yearbook, 2013, 2014 [13]

Table 2 shows the occupied areas (Ha), the largest cultivated areas are with grafted vineyard, and the smallest ones are with table grapes where we have a decrease since 2013 to 2017. In wine grapes the largest cultivated area was in the year 2013.

Table 2. Vineyards on fruit - surface, on property forms

\begin{tabular}{|c|c|c|c|c|c|c|c|}
\hline \multirow{4}{*}{$\begin{array}{l}\text { Vineyards } \\
\text { categories }\end{array}$} & \multirow{4}{*}{ Property forms } & \multirow{4}{*}{$\begin{array}{c}\text { Macroregions } \\
\text { development regions } \\
\text { and counties }\end{array}$} & \multicolumn{5}{|c|}{ Years } \\
\hline & & & 2013 & 2014 & 2015 & 2016 & 2017 \\
\hline & & & \multicolumn{5}{|c|}{$\mathrm{Ha}$} \\
\hline & & & Ha & Ha & Ha & Ha & Ha \\
\hline \multirow{3}{*}{$\begin{array}{c}\text { Totally } \\
\text { - fruit } \\
\text { vineyards }\end{array}$} & Total & Vrancea & 25351 & 23791 & 24267 & 24176 & 24355 \\
\hline & Private sector & Vrancea & 25020 & 23459 & 24024 & 24072 & 24251 \\
\hline & $\begin{array}{l}\text { of which: Individual } \\
\text { agricultural holdings }\end{array}$ & Vrancea & 21968 & 21188 & 21678 & 21713 & 22121 \\
\hline \multirow{3}{*}{$\begin{array}{c}\text { Grafted } \\
\text { vineyard }\end{array}$} & Total & Vrancea & 22515 & 20954 & 21429 & 21282 & 21512 \\
\hline & Private sector & Vrancea & 22184 & 20622 & 21186 & 21205 & 21408 \\
\hline & $\begin{array}{l}\text { of which: Individual } \\
\text { agricultural holdings }\end{array}$ & Vrancea & 19136 & 18356 & 18848 & 18883 & 19286 \\
\hline \multirow{3}{*}{$\begin{array}{l}\text { Hybrids } \\
\text { vineyards on } \\
\text { the fruit }\end{array}$} & Total & Vrancea & 2836 & 2837 & 2838 & 2894 & 2843 \\
\hline & Private sector & Vrancea & 2836 & 2837 & 2838 & 2867 & 2843 \\
\hline & $\begin{array}{l}\text { of which: Individual } \\
\text { agricultural holdings }\end{array}$ & Vrancea & 2832 & 2832 & 2830 & 2830 & 2835 \\
\hline \multirow{3}{*}{ Table grapes } & Total & Vrancea & 4619 & 3889 & 3886 & 3872 & 3889 \\
\hline & Private sector & Vrancea & 4617 & 3886 & 3884 & 3870 & 3887 \\
\hline & $\begin{array}{l}\text { of which: Individual } \\
\text { agricultural holdings }\end{array}$ & Vrancea & 4543 & 3845 & 3836 & 3836 & 3838 \\
\hline \multirow{2}{*}{ Wine grapes } & & Vrancea & 20732 & 19902 & 20381 & 20304 & 20466 \\
\hline & & Vrancea & 20403 & 19573 & 20140 & 20202 & 20364 \\
\hline
\end{tabular}

Source: Romania’s Statistical Yearbook, 2013 -2017 [13]

Table 3 shows the grape production obtained at ha on property forms, the largest wine grape productions were obtained in 2013 and in 2017. The weakest harvests were obtained in 2014 respectively. 
Table 3. Total grape production, by ownership

\begin{tabular}{|c|c|c|c|c|c|c|c|}
\hline \multirow{4}{*}{$\begin{array}{l}\text { Vineyards } \\
\text { categories }\end{array}$} & \multirow{4}{*}{$\begin{array}{l}\text { Property } \\
\text { forms }\end{array}$} & \multirow{4}{*}{$\begin{array}{c}\text { Macroregions } \\
\text { development regions } \\
\text { and counties }\end{array}$} & \multicolumn{5}{|c|}{ Years } \\
\hline & & & 2013 & 2014 & 2015 & 2016 & 2017 \\
\hline & & & \multicolumn{5}{|c|}{ Tons } \\
\hline & & & Tons & Tons & Tons & Tons & Tons \\
\hline \multirow{3}{*}{$\begin{array}{c}\text { Totally } \\
\text { - fruit } \\
\text { vineyards }\end{array}$} & Total & Vrancea & 167556 & 133592 & 143798 & 140436 & 171567 \\
\hline & Private sector & Vrancea & 164084 & 131857 & 141899 & 139468 & 170529 \\
\hline & $\begin{array}{l}\text { of which: Individual } \\
\text { agricultural holdings }\end{array}$ & Vrancea & 141028 & 117524 & 123384 & 119388 & 154868 \\
\hline \multirow{3}{*}{$\begin{array}{c}\text { Grafted } \\
\text { vineyard }\end{array}$} & Total & Vrancea & 152269 & 123496 & 133518 & 130542 & 152196 \\
\hline & Private sector & Vrancea & 148797 & 121761 & 131619 & 129777 & 151158 \\
\hline & $\begin{array}{l}\text { of which: Individual } \\
\text { agricultural holdings }\end{array}$ & Vrancea & 125774 & 107457 & 113156 & 109955 & 135542 \\
\hline \multirow{3}{*}{$\begin{array}{c}\text { Hybrids } \\
\text { vineyards on } \\
\text { the fruit }\end{array}$} & Total & Vrancea & 15287 & 10096 & 10280 & 9894 & 19371 \\
\hline & Private sector & Vrancea & 15287 & 10096 & 10280 & 9691 & 19371 \\
\hline & $\begin{array}{l}\text { of which: Individual } \\
\text { agricultural holdings }\end{array}$ & Vrancea & 15254 & 10067 & 10228 & 9433 & 19326 \\
\hline \multirow{3}{*}{ Table grapes } & Total & Vrancea & 33067 & 23377 & 27524 & 25686 & 27347 \\
\hline & Private sector & Vrancea & 33047 & 23354 & 27506 & 25666 & 27327 \\
\hline & $\begin{array}{l}\text { of which: Individual } \\
\text { agricultural holdings }\end{array}$ & Vrancea & 32400 & 23130 & 27150 & 25350 & 26962 \\
\hline \multirow{3}{*}{ Wine grapes } & Total & Vrancea & 134489 & 110215 & 116274 & 114750 & 144220 \\
\hline & Private sector & Vrancea & 131037 & 108503 & 114393 & 113802 & 143202 \\
\hline & $\begin{array}{l}\text { of which: Individual } \\
\text { agricultural holdings }\end{array}$ & Vrancea & 108628 & 94394 & 96234 & 94038 & 127906 \\
\hline
\end{tabular}

Source: Romania’s Statistical Yearbook, 2013 -2017 [13]

\subsection{Study area}

The geographical location of the Vrancea County is defined by the intersection of the parallel$45^{\circ}$ North latitude and the meridian $-26^{\circ}$ East longitude, which gives it an external position to the Carpathian Curve, in the South-East of Romania. In relation to the neighbouring administrative units of the same rank, Vrancea is bordered by Bacau County to the North, Vaslui to the North-East, Galaţi to the East, Brăila to the South-East, Buzău to the South and Covasna to the West. The major relief units that define the position of Vrancea County are the Vrancea Mountains, which occupy the western third, the sub-Carpathian sector between and Zăbrauţi and Râmnicu Sărat in the central area and the central part with the Siret Plain, which covers the eastern third. Within these limits the county totals $4857.03 \mathrm{~km}^{2}$.

The climatic characteristics of Vrancea County are those specific to the situation at northern latitude of $46^{\circ}$ and in the continental area. These two elements determine the temperate transition continental climate, with specific characters determined by the altitudinal floor (from the level of the plain, up to over $1700 \mathrm{~m}$ ). And with local influences that impose topo climate of depression type. The layout of the relief in steps, which descend to the east, opens wide space, first of all, to the east-continental influences but at the same time to the influences of northern and southern climate. At the same time, the Carpathians Curvature has the function of a natural discharge for the western air masses.

To create hypsometric map, soil map, relief unit's map and CLC map using the software ArcGIS 10.5 was used digital elevation model (DEM) with a resolution of $30 \mathrm{~m}$, Corine Land Cover 2000, Soil Map of Romania at 1: 200000 scale. 
The DEM was downloaded free from (www://geo-spatial.org) and all the used vectors were downloaded free from (http://www.opengis.org). The use of land map was obtained from CORINE Land Cover. [10] [12]

The CORINE Land Cover is a vector map with a scale of 1:100 000, a minimum cartographic unit (MCU) of 25 ha and a geometric accuracy better than 100m. It maps homogeneous landscape patterns, i.e. more than $75 \%$ of the pattern has the characteristics of a given class from the nomenclature. This nomenclature is a 3-level hierarchical classification system and has 44 classes. In order to deal with areas smaller than 25 ha a set of generalisation rules were defined. [4]

The Hypsometric map was the first created map (Figure 1). The role of hypsometric map is to show how altitude varies within the studied area. Vrancea County is divided into 6 altitudinal classes. The altitude varies between $4-1.774 \mathrm{~m}$. [7]

The largest area is occupied by the plain area between $4-364 \mathrm{~m}$ (green color) in the East. In the western part are the sub-Carpathian hills area $(365-843 \mathrm{~m})$ followed by the mountains (brown and white colour).

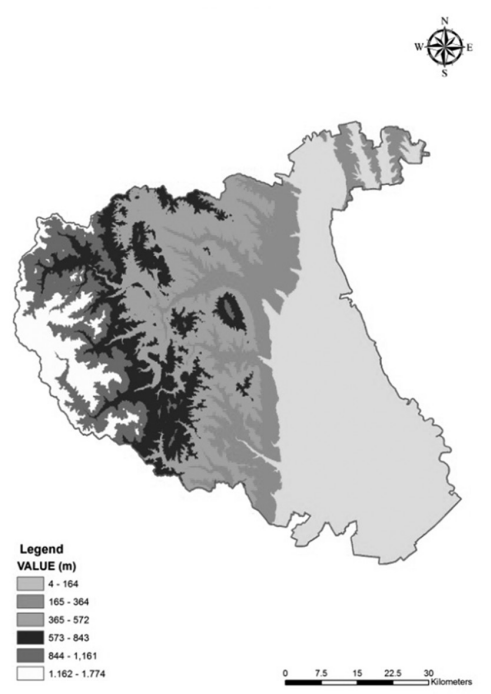

Figure 1. The hypsometric map of study area

Vrancea County has a high natural potential. Regarding, the soil, the renewable resource, from the East to the West, we notice the following zone characteristics:

- the plain area;

- the sub-Carpathian hills area;

- the mountain area.

The lower Siret Plain and the Ramnic Plain are characterized by alluvial soils in the meadows and lowlands. Chernozems are characteristic on the interfluves and the gray soils are in the contact area of the plain with the sub-Carpathian hills.

In the area of the sub-Carpathian hills there are brown podzolite, podzolic, clay-alluvial and brown soils that offer favourable conditions for the pastures, meadows and forest vegetation development. In this area, agricultural crops find less favorable conditions. It is the relief step of the surfaces occupied by orchards and vineyard plantation. 
The mountain area is characterized by acid brown soils and podzolic brown soils which have led to the forest steps vegetation development consisting of mixing forests (deciduous forests) at altitudes below $900 \mathrm{~m}$ and at altitudes between 900 and $1600 \mathrm{~m}$, also. At higher altitudes are developed spruce forests, alpine meadows, blueberries, alder and juniper.

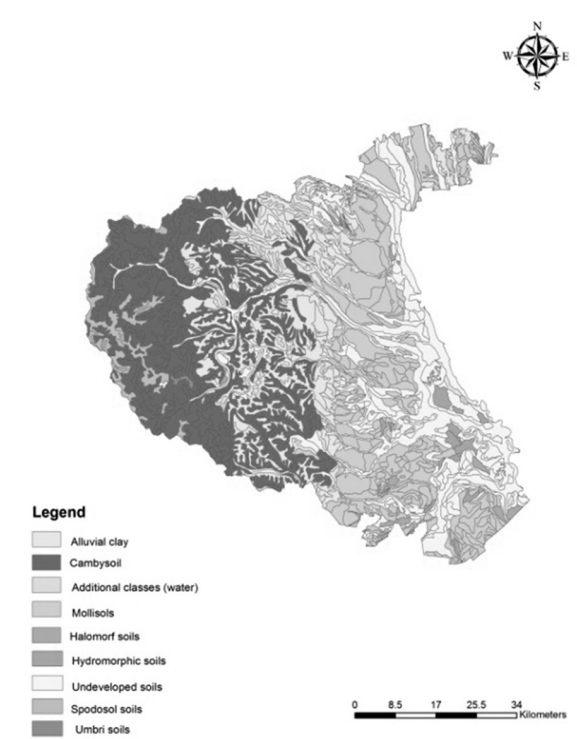

Figure 2. The soil map of study area

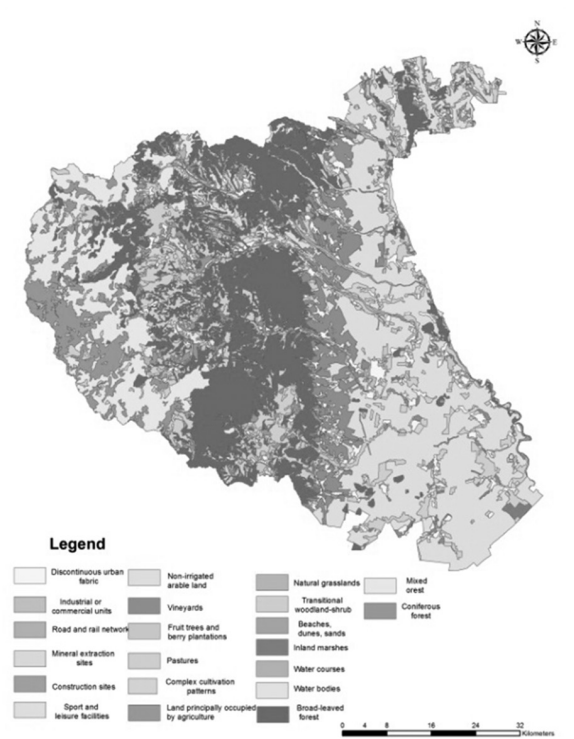

Figure 3. The land use map of study area

The Corine Land Cover map provides information on how the lands in the study area are used. The analysis of the map shows that the area with the greatest viticulture potential is in the sub-Carpathian hills. This area is delimited in the northern part of the forests and in the south of the fruit trees and berry plantation. (Figure 3) [1]

The relief map shows how the relief units are distributed in Vrancea County. The plain units are located in the eastern areas; the western part is the area of the sub-Carpathian hills. Here are located most vineyards plantation in the Vrancea County. (Figure 4)

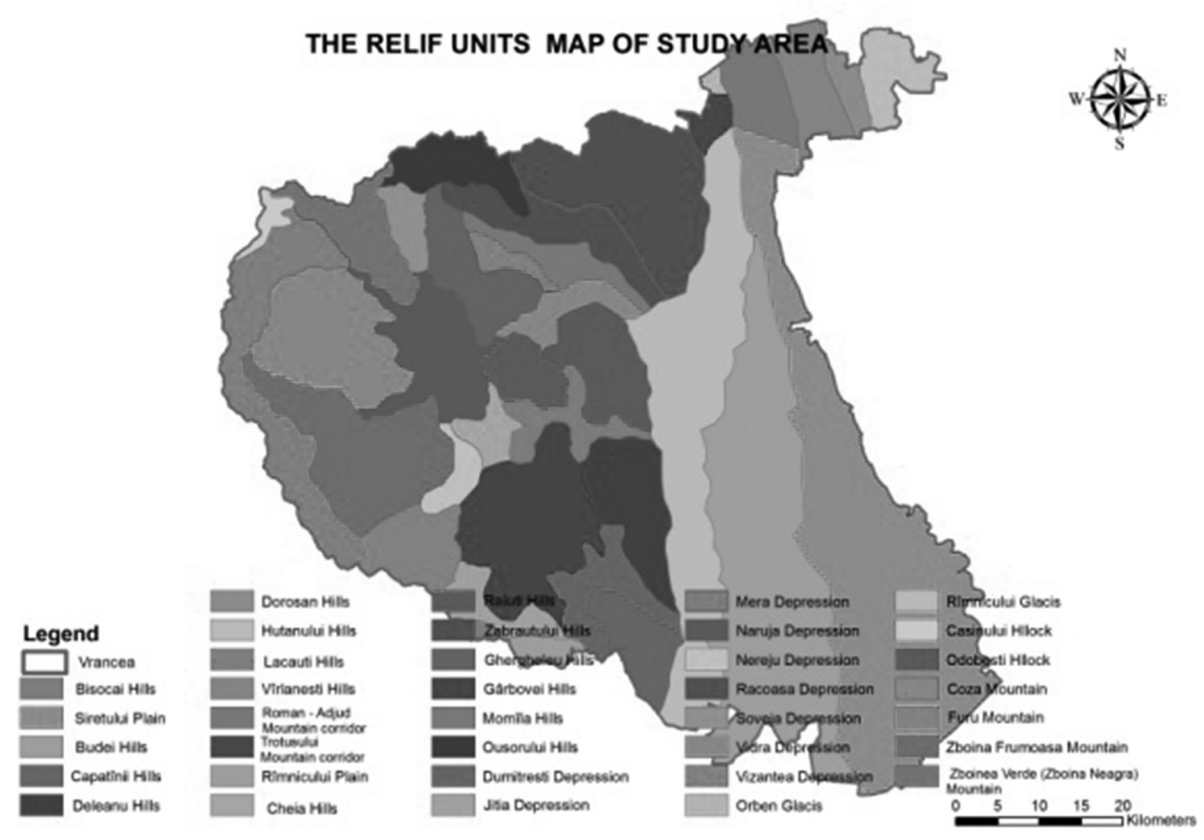

Figure 4. The relief units map of study area 


\section{CONCLUSION}

Productivity is a fundamental characteristic of any agricultural plant; it is appreciated after the economic weight of the main product made at the surface unit. In the case of vineyards, the main economic product consists of grapes. [2]

Grape production is actually the result of a heterogeneous complex of interactions between varieties, biotope conditions and the technology used. It is ultimately conditioned by all the factors that influence in some way the potential and actual fertility as well as the growth processes. The better the biotope conditions are in harmony with the biological requirements of the variety, the higher-level production.

Each variety is characterized in terms of production by a certain biological potential. Some more vigorous varieties, in general, ensure large grape production (15 - 22t/ha and even more) (Galbena de Odobesti, Zghihara de Husi, Berbecel, Black Babeasca among the varieties of wine, Afuz Ali, Italy, Cardinal among those for the table). Other varieties such as: Grasă de Cotnari, Pinot, Tamaioasa romanesca, Cabernet Sauvignon, show other biological and productive properties and give smaller grape productions $(5-10 \mathrm{t} / \mathrm{ha})$, but with higher quality performances.

\section{REFERENCES}

[1] Bajocco S., De Angelis A., Perini L., Ferrara A., (2012) The impact of Land use/Land Cover Changes on Land Degradation Dynamics. A Mediterranean case Study, Environmental Management, May 2012, Issue 5, pp 980 -989

[2] Creasy, G. L., Creasy L. L., (2009). Crop Production Science in Horticulture, Volume 16: Grapes. Wallingford, Oxon, GBR: CABI Publishing, p 117.

[3] Dumitriu I. C., (2008) Viticultura, Editura Ceres, Bucureşti

[4] Kasereka K., Yansheng G., Mbue I.N., Samake M., (2010) Remote sensing and geographic information system for interfering land cover and land use change in Wuhan (China), 1987-2006 Journal of Sustainable Development, Vol 3, No. 2, pp 221 -229

[5] Leonowicz A.M., Jenny B., Humi L., - (2009) Automatic generation of hypsometric layers for small scale maps, Computers and Geosciences 35 (10), October 2009, pp 2074 -2083

[6] Neamţu, I., (1994), Viticultura practică, Ed. Ceres, Bucureşti

[7] Patton J.C., Crawford P.V., (2013) The perception of hypsometric colours - The cartographic Journal, volume 14, pp $115-127$

[8] Robinson, J. (1986). Vines, grapes \& wines, Oxford University Press

[9] Smart, R.E., Robinson M.D., (1991), Sunlight into Wine: A Handbook for Wine-Grape Canopy Management, Wine Titles, Hyde Park Press, Adelaide, Australia

[10] www://geo-spatial.org

[11] https://land.copernicus.eu/pan-european/corine-land-cover/clc-2000.

[12] http://www.opengis.org

[13] http://www.insse.ro/cms/ 